Cписок бібліографічних посимань

1. Капська А.Й. Соціальна робота: деякі аспекти роботи з дітьми та момоддю. Київ.: УДЦССМ, 2001. 220 c.

2. Никитина Н. И. Методика и технология работы социального педагога: учеб. пособие дмя студентов. Москва.: Гуманитарный Центр. ВААДОС, 2005. 399 c.

3. Соціальна робота в Україні/ під ред. Звєрєвої У.Д., Аактінової Г.М. Київ, 2004. 296 с

4. Соціальна робота: технологічний аспект/ Під ред. Капської А.Й. - Київ., 2004. 317 с.

5. Томчук M.I., Комар Т.О. Особливості виховання студентів з особливими потребами Нові технології навчання. Науково-методичний збірник. 2001. Вип. 31. С. 198-205.
References

1. Kapska A.Y. Social work: some aspects of working with children and young people. Kyiv .: UDCSSM, 2001. 220 p.

2. Nikitina N.I. Methods and technology of social pedagogue working: study guide for students. Moscow: Humanitarian Center. VLADOS, 2005. 399 p.

3. Social Work in Ukraine / ed. Zveryeva U.D., Laktinova H.M. Kyiv, 2004. - 296 p.

4. Social Work: Technological Aspect / Ed. Kapska A.Y. Kyiv., 2004. 317 p.

5. Tomchuk M.I, Komar T.O. Features of students' upbringing with special needs. New learning technologies. Scientific and methodical digest. 2001. Publ. 31. p.p. 198-205.

PLATONOVA Oxana,

Ph.D in Pedagogy, Associate Professor of Social Work Department,

T.H. Shevchenko National University "Chernihiv Colehium"

\title{
PROBLEM OF SOCIALIZATION OF DISABLED CHILDREN
}

Introduction. The current stage of socio-economic development of Ukraine and the crisis in economy and finance determine the need to intensify social protection of children with functional disabilities and prioritize the dominant areas in this essential work. Besides financial support, disabled children need medical, professional and social rehabilitation measures. In its turn, this requires creating appropriate conditions conducive to realizing their abilities, developing personal traits, and satisfying the needs in social, moral and spiritual self-improvement.

Purpose. The article is aimed at considering main problems with socialization of disabled children.

Results. Social work with children with functional disabilities to ensure their successful socialization requires the society to create a network of rehabilitation centers for such groups of children. The basic task for these centers is to provide vocational guidance through training, legal advice, and specific employment assistance.

The most important role in upbringing, socialization, satisfaction of needs, teaching children with functional disabilities is allotted to their families, the closest environment that children encounter. Under existing conditions, families with disables children have to solve a large number of problems: domestic, psychological, and financial, those related to medical and social rehabilitation of children. Simultaneously, parents are in need of expanding their social contacts with different institutions and organizations.

At present, there are numerous problems related to upbringing of disabled children, specifically, psychological problems of parents; psychological problems of children with functional disabilities; educational problems; communication problems between parents and children functional disabilities.

Conclusion. To sum up, children with disabilities tend to integrate into society, they do not want to be outside of it and exist in isolation. Notwithstanding, they understand that they can live like other children. However, this requires some conducive conditions, which can be ensured only by joint efforts of the state and parents. Therefore, for the harmonious development of disabled children, it is necessary to create a complex set of conditions for their socialization that would satisfy their needs.

Keywords: children with disabilities; conditions of socialization of children; families who bring up children with special needs.

Одержано редакиією 09.01. 2019 рік Прийнято до публікаиї̈ 16.01.2019 рік

DOI 10.31651/2524-2660-2019-1-176-181

ORCID 0000-0003-0547-6828

БОГАТІКОВ Юрій Омексійович,

керівник громадського науково-дослідницького міждисциплінарного проекту "Аутизм: сьогодні і завтра"

e-mail: bogat080808@ukr.net

ORCID 0000-0002-6714-9913

ЧЕРНIKОВА Натапія Миколаївна,

педагог-абілітолог, корекційний центр "Баланс" e-mail: natali080818@ukr.net

УДК: 159.98-048.25-053.2:616.896]:37.018.1(045)

\section{ЗНАЧЕННЯ УЧАСТІ БАТЬКІВ У КОРЕКЦІЇ АУТИЧНОЇ ДИТИНИ}

Розглядаються питання участі батьків та інших иленів родини у проиесі абілітаиї, розвитку, корекиії та соиіалізаиї дитини з аутизмом та іншими порушеннями розвитку. Наголошуеться на важливості та необхідності проведення такої роботи. Підкреслюється, шоо підвищення ролі батьків у вихованні дітей з вадами розвитку розглядається на глобальному рівні як один з чинників покращення поточного стану таких дітей та покращення прогнозу стосовно їхнъого подальшого розвитку. В якості одного з найважливіших чинників, шо закладають засади для зменшення аутичних проявів $у$ дитини, розглядається створення сприятливого психоемоиійного оточення у місиі переважного перебування дитини та в ї родинному колі. 
Таким чином, забезпечуеться розширення зони психологічного комфорту дитини, шо сприяе зменшенню ї̈ психологічної закритості. На прикладі окремої родини продемонстровано, шо постійна, послідовна та наполеглива робота батьків по корекиї та соиіалізаиї̈, ио проводиться на базі вітчизняних педагогічних методик з деякою адаптаиією їх до індивідуальних особливостей дитини, здійснювана у співпраиі з дефектологами та корекиійними педагогами, приводить до подолання низки порушень розвитку та зменшенню аутичних проявів у дитини.

Ключові слова: розвиток; абілітаиія; соиіалізаиія; психологічний комфорт; мультидисииплінарний підхід; аутичні прояви; розвиток мовлення; вітчизняна педагогіка.

Постановка пробцеми. Організація родинного виховання протягом тривалого часу залишається сферою, недостатньо дослідженою дия педагогів та психомогів. Разом з тим правильне родинне виховання має непересічне значення дия формування психічно, інтелектуально та морально здорової особистості, оскільки у переважній більшості саме батьки справАяють найбільший вплив на дитину протягом сензитивного періоду [1, ст. 3 п. 2 , ст. 5] Що стосується дітей з вадами розвитку, то роль батьків у вихованні такої дитини суттєво збільшується порівняно 3 нейротиповими дітьми.

Мета. Ця стаття має на меті показати ефективність вітчизняних наукових розробок у сфері корекційної педагогіки та психології на прикладі практичного застосування цих досягнень, взаємоузгодженості дій всіх учасників процесу, особливо батьків, іххньої наполегливості, дисциплінованості і підвищення обізнаності. Досягнуті результати роботи були відзначені доктором педагогічних наук академіком В. М. Синьовим як позитивні та такі, що заслуговують вивчення та поширення на відповідні категорії дітей.

Важмивість залучення батьків до корекційного процесу. Вітчизняна корекційна педагогіка і психологія має потужну i розвинену теоретикометодологічну базу для здійснення психокорекційної роботи 3 аутичними дітьми. При дослідженні і вирішенні різних педагогічних i психологічних проблем вона виходить 3 необхідності дотримання справжніх об'єктивних інтересів дитини та поєднання іх з об'єктивними інтересами суспільства. Такий підхід властивий нашому менталітету. При цьому, на думку доктора педагогічних наук професора М.K. Шеремет, на передній план висувається такий важливий аспект, як активна участь у процесі корекції батьків і чценів родини такої дитини, які, у свою чергу, мають бути підготовмені відповідними фахівцями - як результат консультацій батьків дитини та ix професійного супроводу [2].

Особливого значення набуває роль батьків та родини загалом у вихованні дітей з аутизмом, яке вкАючає в себе корекцію розвитку, в т.ч. і мовценнєвого, цікування, абілітацію та соціалізацію. Існуючий досвід спостереження за аутичними дітьми показує, що така дитина психологічно є дуже прив'язаною до сім'ї, особливо до матері. Результати багатьох досліджень, зокрема,. .С. Печнікової [3, с. 73-74], показують, що, незалежно від ступеня тяжкості аутичного розцаду у дитини, у матері існують труднощі в розумінні своєї дитини, у створенні моделі іiі виховання та можливості включення дитини в соціальне середовище. ВООЗ рекомендує стосовно дітей, що входять до груп ризику розвитку як соматичних, так i психоневрологічних захворювань, пропонувати заходи, що сприяють покращенню взаємодії між матір'ю та дитиною, включаючи психосоціальне стимуюювання, з метою покращення показників розвитку дітей. Ступінь цієї рекомендації $є$ настійливим, тобто група з розробки керівних принципів впевнена в тому, що дмя більшості пацієнтів рекомендовані заходи є необхідними, а особи, що формують політику, можуть мегко адаптувати цю рекомендацію в якості політики в більшості ситуацій [4]. Об'єктивними підставами дмя обов'язкового вкАючення батьків в процес корекції розвитку дитини з аутизмом є:

- можливість постійного спостереження за дитиною, тобто виявлення особливостей поведінки, специфіки вираження емоційно-вольових проявів, причинно-наслідкового зв'язку між психологічними або сенсорними подразниками і реакцією дитини на них;

- психологічний та емоційний зв'язок між дитиною і батьками;

- постійний контакт 3 дитиною.

Це дає можливість збору інформації дия того, щоб разом з психологом та дефектологом побудувати індивідуальну систему роботи з дитиною, яка буде максимально адекватна іiі психофізіологічному стану, та втілювати ії в життя.

Практична участь батьків у корекційній роботі. На початку нашої роботи стан комунікативних зв'язків між учасниками процесу, нами як батьками, самою дитиною та оточуючим середовищем виглядала таким чином (рис. 1): 


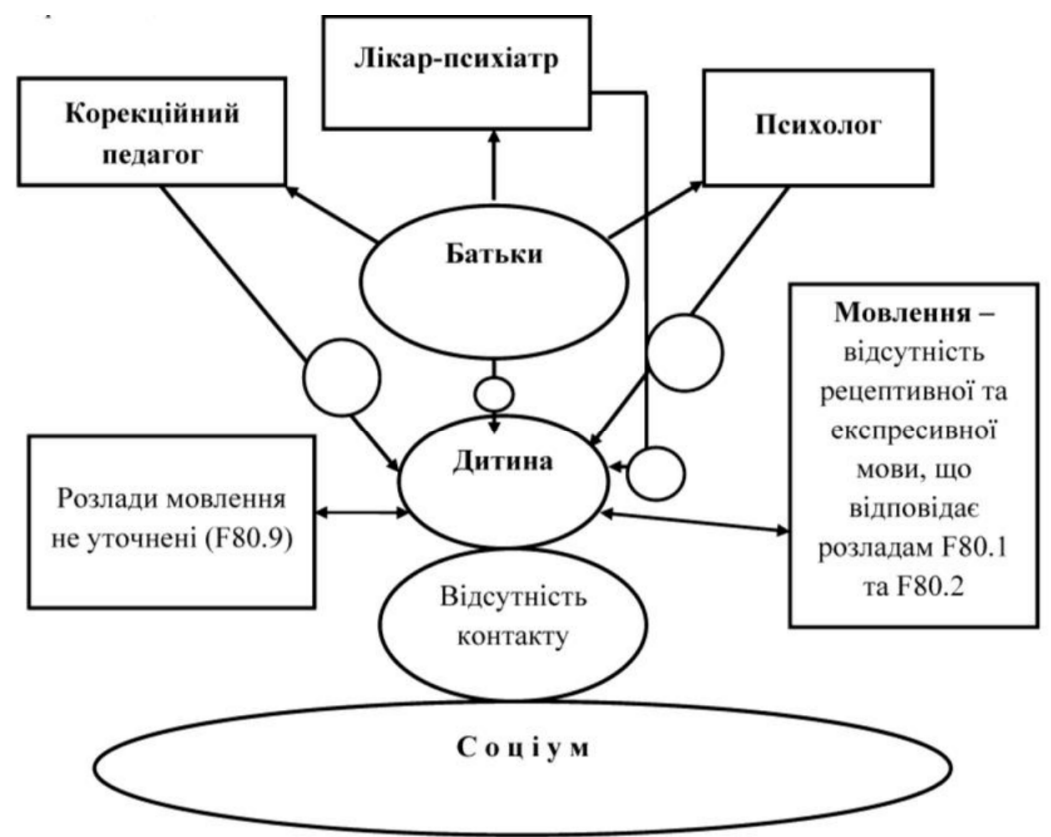

Рис. 1. Стан комунікативних зв'язків між учасниками Аікувально-корекційного процесу, батьками дитини, самою дитиною та оточуючим середовищем

Ця схема (рис. 1) демонструє, що аутичний стан дитини робить її закритою для будь-яких контактів, в тому числі і 3 батьками, оскільки вони, зазвичай, є необізнаними у специфіці стану дитини.. Це $\epsilon$ причиною звернень по допомогу до відповідних фахівців (психіатрів, дефектологів, психологів).

3 огляду на те, що ці фахівці проводять роботу з дитиною кожен у своєму напрямку, виникає необхідність здійснення зв'язку між ними дмя забезпечення позитивного результату комплексного мультидисциплінарного підходу до мікування та педагогічної корекції дитини. Ми, як батьки, стали цією манкою.

Наша дослідницько-практична робота протягом 2013-2018 рр. має два напрями: педагогічний та медичний (як цільове рандомізоване дослідження процесу психомовного розвитку під загальним наглядом доктора медичних наук професора $\Lambda$.О. Булахової), де проміжні показники $\epsilon$ результатом проведення нефармакологічного мікування [5, пп. 15, 16] та психолого-педагогічної корекції та фіксуються у порівняльних таблицях.

Здійснюваний комплексний підхід до корекційної роботи у своїй основі містить контроль фізіологічного комфорту дитини, тобто задоволення всіх іiі фізіологічних потреб, та її психологічного комфорту, як відсутність фруструючих чинників, а також чинників, що викликають ії збудження, занепокоєння та ін., забезпечуючи належний психофізіологічний стан, сприятливий для проведення занять, тощо.
Підтримання фізіологічного комфорту базувалося на організації правильного здорового харчування [6] та організації повноцінного відпочинку, тобто регуляції сну.

Дмя подомання розцадів прийому їжі (F50) та розладів сну (F51) проводимось нефармакологічне мікування, розроблене Ю.О. Богатіковим. Що стосується психомогічного комфорту, то його необхідність підтверджена в процесі нашої роботи протягом 2013-2018 pp. Тоді було з'ясовано, що аутична дитина здатна сприймати позитивний або негативний емоційний стан оточуючих і реагувати на нього відповідно до своїх психічних особливостей. Тому ми сформували всередині сім'ї позитивну емоційну атмосферу, яка ситуативно набуває конструктивно-творчого, навчально-ділового або ігрового характеру. Така атмосфера сприяє зменшенню психологічної замкненості та полегшує встановлення контакту з дитиною, а отже, зменшує глибину аутичного розцаду (F84.0) та сприяє розвитку мовлення (F80.9). Велике значення також мало вироблення комплексу наших реакцій на позитивні і негативні дії дитини. Будь-яку позитивну, прогресивну дію ми відзначаємо, схвалюємо та фіксуємо у відповідній категорії (емоційній, творчій, навчально-діловій або ігровій) з метою подальшого розвитку. Щодо проявів негативної поведінки наша практика показує, що дмя успішної соціалізації та соціальної адаптації потрібно класифікувати види негативної поведінки i розробити варіанти реагування на кожен 3 них. У цій роботі за основний 
принцип нами бумо взято конструктивний перевод до однієї 3 категорій 3 обов'язковим переходом у соціально прийнятну форму поведінки.

За необхідності ми застосовувами прийоми поведінкової терапії дмя заохочення виконання запропонованих завдань.

Психолого-педагогічна корекція доповнюється фізіологічно обгрунтованим фізичним навантаженням, що реалізується шляхом виконання низки фізичних вправ та організації системної трудотерапії [6], яка полягає у виконанні різноманітних побутових та деяких сільськогосподарських операцій, при чому основна увага приділяється сумісному виконанню кожної операції.

Підготовка батьків до участі у корекційній роботі. Принципи нашої практичної роботи грунтуються, насамперед, на психологічній і освітній підготовці батьків як по формуванню власного позитивного психоемоційного стану, так і по створенню мінії поведінки стосовно дитини. Дослідження ВООЗ говорять про те, що наявність психологічної підготовки батьків у сфері поводження 3 дітьми з емоційними і неврологічними розмадами, а також з порушеннями розумового розвитку, і застосування цієї підготовки на практиці істотно покращує стан дитини [4].

Таким чином, важливе значення, поряд з організацією корекційної роботи 3 аутичними дітьми, набуває освітньопсихомогічна робота $з$ їх батьками та іншими членами сім'ї, що проживають 3 ними постійно [7, с. 291-292]. Цей підхід базується на принципах найкращого забезпечення інтересів дитини, що повинно бути керівним принципом дмя тих, на кому межить відповідамьність за їі освіту та навчання; ця відповідамьність межить перш за все на іiі батьках [8, принципи 6, $7 ; 9$, ст. 28, в), с), d), ст. $44,47 \mathrm{~h})]$.

Стан комунікативних зв'язків між учасниками процесу, до якого повною мірою вкАючені батьки, дитиною та соціумом відображений на рис. 2:

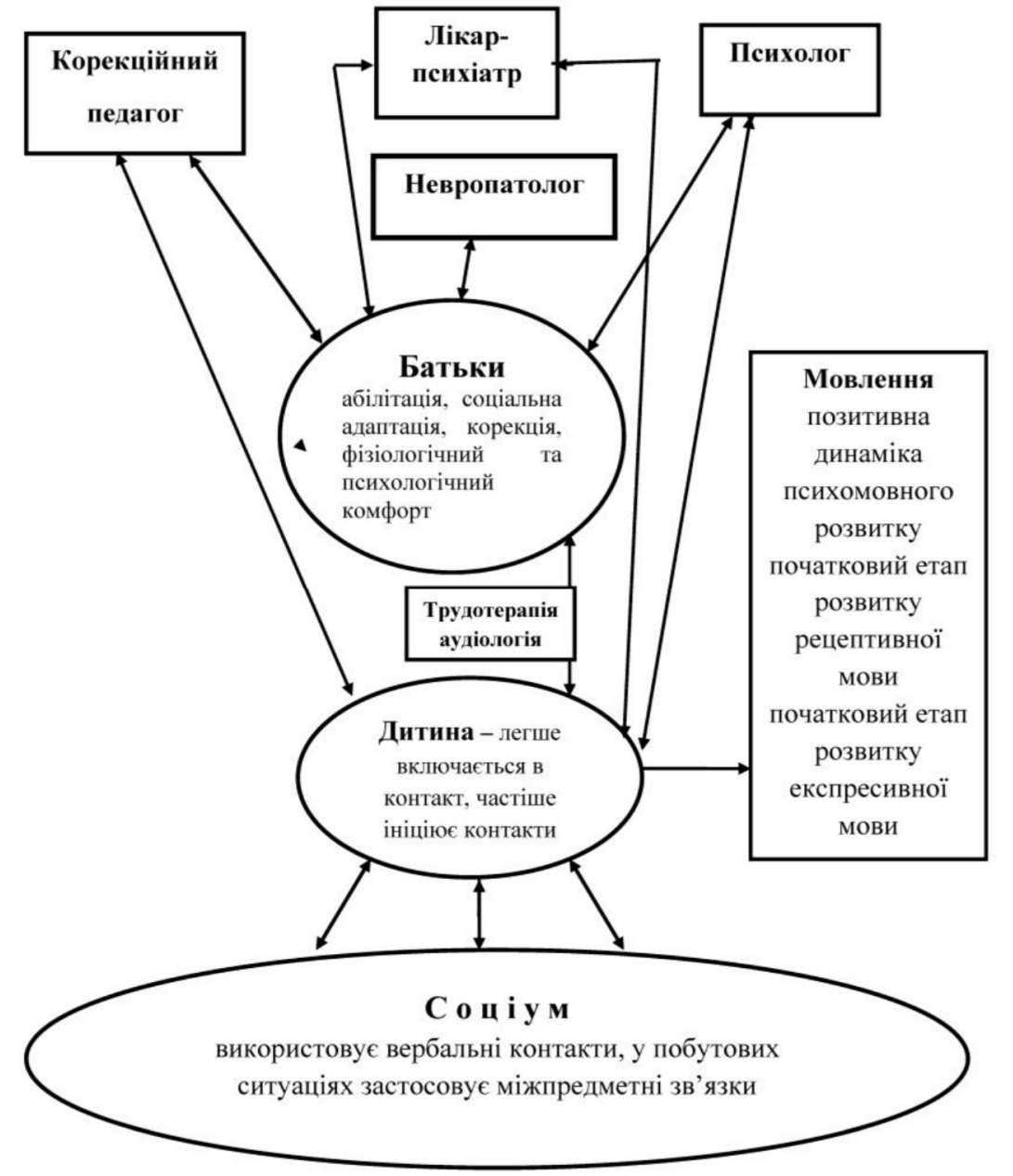

Рис. 2: Стан комунікативних зв'язків між батьками, дитиною, учасниками Аікувально-корекційного процесу та оточуючим середовищем в результаті системного поєднання комплексу заходів нефармакологічного мікування, корекційного та навчально-розвиваючого характеру.

Ця схема наочно ілюструє, як з'явцяється зворотній зв'язок у комуніка- тивній сфері психіки дитини, а отже, зменшуються прояви аутизму (F84.0), 
коли корекційно-терапевтичний вплив на дитину, крім педагогів, мікарів і психомогів, здійснюють ще й батьки, чиї знання про стан психіки і психології дитини збагачені взаємодією з зазначеними фахівцями, - перш за все, завдяки тому, що відбувається інтенсифікація психолого-педагогічної роботи 3 дитиною, опосередкованої батьками.

Резуиьтати вкиючення батьків у корекційну роботу. Наведений приклад демонструє підвищення ефективності корекційної роботи та подолання аутистичних проявів за умови взаємоузгодженості дій всіх учасників цього процесу у практичному застосуванні досягнень вітчизняної науки, а також наполегливості, дисциплінованості та підвищення обізнаності батьків.

Застосована нами методика, напрацьована в ході дослідницько-практичної роботи протягом 2013-2018 рр. являє собою поєднання комплексу заходів нефармакологічного мікування, корекційного та навчамьно-розвиваючого характеру, що проводяться батьками стосовно своєї дитини самостійно, а також у співпраці 3 медичними працівниками та працівниками освіти. Вона $\epsilon$ ефективною, безпечною, позитивною, і може бути застосована на будь-якому етапі розвитку дитини.

Висновки. Таким чином, виникає необхідність створення системи психоосвітньої підготовки дмя батьків дітей 3 особливими потребами та системи індивідуамьної роботи фахівців 3 родиною, зразки якої вже існують у зарубіжному досвіді [10, с. 234-268], а також включення питання підвищення відповідальності батьків за виховання дитини. вже зараз, на рівні програм підготовки майбутніх педагогів у сфері організації роботи з батьками [9, ст. 44, 47h)].

\section{Cписок бібиіографічних посимань}

1. Конвенція ООН про права дитини, прийнята резолюцією 44/25 Генеральної Асамблеї від 20.11.1989 p. URL: http://www.un.org/ru/documents/decl_conv/conv entions/childcon.shtml

2. Шеремет М.К. Проблеми та перспективи спеціамьної освіти. Збірник наукових праиь Кам'янеиьПодільського державного університету імені Івана Огієнка. Серія Соиіально-педагогічна. Кам'янець-Подільський: Мошинський В. С., 2007. Вип.VIII. С. 101-103.

3. Печникова М.С. Материнское отношение к ребенку-аутисту в зависимости от наличия в семье здорового сибса. Соииальное и душевное здоровъе ребенка и семьи: зашита, помошь, возврашение в жизнь: материалы рос. науч.-практ. конф., Москва, 22-25 сент. 1998 г. М., 1998.
4. Рекомендації ВООЗ по веденню психічних розмадів у дітей та підмітків у неспеціалізованих медичних закладах. URL: https://www.who.int/mental_health/mhgap/evide nce/child/ru/

5. Резолюція Всесвітньої Асамблеї Охорони Здоров'я A67/26 14.03.2014 p. URL: apps.who.int/gb/ebwha/pdf_files/WHA67/A67_26 -ru.pdf

6. Програми трудотерапії та науки про харчування Каромінського Iнституту. URL: https:/ / ki.se/programme/1AR15/18-19, https://ki.se/programme/3NT18/18-19

7. Шульженко Д.І. Основи психологічної корекції аутичних порушень у дітей: Монографія. Київ, 2009. 385 c

8. Декларація прав дитини, прийнята резолюцією 1386 (XIV) Генерамьної Асамблеї ООН від 20.11.1959 p. URL: http: / / www.un.org/ru/documents/decl_conv/decl arations/childdec.shtml

9. Європейський пман дій 3 охорони психічного здоров'я, 2013-2020 рр. ВООЗ. Європейсъкий $P e-$ гіональний Комітет. Шістдесят третя сесія. Чешме, Ізмір, Турція, 16-23 вересня 2013 р. 26 с. URL: EUR/RC63/11+EUR/RC63/Conf.Doc./8.

10. Селигман M., Дарлинг Р. Обычные семьи, особые дети: пер. с ангм. М.: Теревинф, 2007. 368 с.

\section{References}

1. UN Convention on the Rights of the Child, adopted by General Assembly resolution 44/25 of 11.20.1989. Retrieved from http: / / www.un.org/ru/documents/decl_conv/conv entions/childcon.shtml

2. Sheremet, M.K.( 2007). Problems and prospects of special education. Problems and prospects of special education. Collection of scientific works of the Kamyanets-Podilsky State University named after Ivan Ogienko. Socio-pedagogical series. KamyanetsPodilsky: Publisher Moshynsky V.S. VIII. 101-103.

3. Pechnykova, L. S. (1998). Maternal attitude to the child-autistic depending on the presence in the family of healthy sybase. Social and mental health of the child and the family: protection, help, return to life: materials of the Russian scientific-practical conference, Moscow, September 22-25. 1998 Moscow. 45-47 (in Russ.)

4. Evidence-based recommendations for management of child and adolescent mental disorders in nonspecialized health settings. Retrieved from https://www.who.int/mental_health/mhgap/evide nce/child/ru/

5. Resolution of the World Health Assembly A67/26, 14.03.2014. Retrieved from apps.who.int /gb/ebwha/pdf_files/WHA67/A67_26-ru.pdf

6. Programmes sn Nutrition Science and Occupational Therapy at Karolinska Institutet. Retrieved from https:/ / ki.se/programme/1AR15/18-19, https://ki.se/programme/3NT18/18-19.

7. Shulzhenko, D.I. (2009). Basis of psychological correction of autistic disorders in children: monograph. Kiev. 385 p.

8. Declaration on the Rights of the Child, adopted by Resolution 1386 (XIV) of the UN General Assembly of 11.20.1959. Retrieved from http: / / www.un.org/ru/documents/decl_conv/decl arations/childdec.shtml

9. The European Mental Health Action Plan 20132020. Regional Commetee for Europe Sixty-Third Session. Cesme, Izmir, Turky, 16-19 September 2013.

10. Seligman, M., Darling, R. (2007). Ordinary Families, Special Children. "Special Babies" series. Moscow: Terevinf. (in Russ.) 
BOGATIKOV Yuri,

Head of the Public Research Interdisciplinary Project "Autism: Today and Tomorrow"

CHERNIKOVA Natali,

pedagogue-analyst, correction center "Balance"

\section{THE VALUE OF PARENTAL INVOLVEMENT IN THE EDUCATION OF AN AUTISTIC CHILD}

Abstract. The article considers the issues of participation of parents and other family members in the process of habilitation, development, correction and socialization of a child with autism and other developmental disorders. The importance and necessity of such work is noted. It is emphasized that enhancing the role of parents in raising children with developmental disabilities is considered at the global level as one of the factors improving the current state of such children and improving the forecast for their future. Objective reasons for mandatory inclusion of parents in the process of correction of development of a child with autism are:

- the possibility of constant monitoring of the child, that is, the identification of peculiarities of behavior, the specifics of expression of emotional-volitional manifestations, causal relationship between psychological or sensory stimuli and the reaction of the child to them;

- psychological and emotional connection between the child and parents;

- constant contact with the child.

This enables the gathering of information in order to work with the psychologist and defectologist to build an individual system of work with the child that will be as adequate as possible to its psychophysiological state and implement it.

In the discussed case, parents conducted a multidisciplinary combination of recommendations of psychiatrists, psychologists and defectologists. The comprehensive approach to corrective work is based on the control of the physiological comfort of the child, that is, the satisfaction of all of her physiological needs, and her psychological comfort, such as the absence of frustration factors, as well as factors causing her excitement, anxiety, etc., providing the proper psychophysiological state, conducive to occupations, etc.
As a fundamental factor, it lays the foundation for reducing autistic manifestations in a child; it is considered the creation of a favorable psycho-emotional environment in the place of the child's primary stay, that is, in the room where the kid lives and in the family circle. Maintaining physiological comfort was based on the organization of proper healthy eating and organization of full rest, that is, regulation of sleep. The development of a complex of our reactions to the positive and negative effects of the child has a great importance.

Psycho-pedagogical correction is supplemented by physiologically substantiated physical activity, which is realized through the implementation of a number of physical exercises and the organization of system labor therapy, which consists in the implementation of a variety of domestic and some agricultural operations, with the emphasis on the joint execution of each operation.

The principles of our practical work are based, first of all, on the psychological and educational preparation of parents, both on the formation of their own positive psycho-emotional state, and on the creation of a line of behavior concerning the child.

Using the example of an individual family, it has been demonstrated that the constant, consistent and persistent work of parents on correction and socialization, carried out on the basis of domestic pedagogical methods with some adaptation to the individual characteristics of the child, carried out in collaboration with defectologists and correctional teachers, leads to overcoming a number of developmental disorders and reduce autistic manifestations in a child.

Keywords: development; correction; habilitation; socialization; adaptation; autistic manifestations; psychological comfort; domestic pedagogy.

Одержано редакиією 17.01.2019 Прийнято до публікаиіï 21.01.2019

DOI 10.31651/2524-2660-2019-1-181-185

ORCID 0000-0001-5818-4656

\section{ФУЧиАА Омена Микомаївна,}

кандидат педагогічних наук, доцент, доцент кафедри іноземних мов,

Національний університет " $\Lambda$ ьвівська Політехніка" e-mail: helenfuchila@gmail.com

ORCID 0000-0003-4037-4122

\section{БАМАЦЬКА Аюбов Петрівна,}

старший викладач кафедри іноземних мов,

Національний університет " $\Lambda$ ьвівська Політехніка" e-mail: lubov.balatska@gmail.com

УДК 377.018(493.3/.4)

\section{ОСОБАИВОСТІ ОРГАНІЗАЦІЇ ПРОФЕСІЙНОЇ ОСВІТИ ДОРОСАИХ У ФААНДРІЇ (БЕАЬГІЯ)}

у статті розглянуто деякі аспекти професійної освіти дорослих у фрламаномовній спільноті Бельгії (Фландрії). Проаналізовано структуру неформальної професійної освіти дорослих та діяльність двох основних провайдерів неформального профресійного навчання, Фламандсъкої служби зайнятості та професійної підготовки $і$ Фламандсъкої агениї підприємниитва (ФАП) - Синтра Фландерс. Відмічено переваги та недоліки неформальної профресійної освіти дорослих Фландрії та проблеми залучення громадян до навчання у ній.

Ключові слова: Фландрія (Бельгія); нефрормальна профресійна освіта дорослих; ринок праиі; навчання підприємниитву; підвищення квалірікаuіï.

Постановка проблеми. Розглядаючи різні аспекти професійної освіти доросмих, потрібно зауважити, що в епоху гцобалізації та стрімких змін ринку праці в 